\title{
The effect of prepartum intravaginal bacteriophage administration on the incidence of retained placenta and metritis
}

\author{
E. B. S. Meira Jr., R. S. Rossi, A. G. Teixeira, C. Kaçar, G. Oikonomou, L. Gregory, and R. C. Bicalho ${ }^{1}$ \\ Department of Population Medicine and Diagnostic Sciences, College of Veterinary Medicine, Cornell University, Ithaca, NY 14853
}

\section{ABSTRACT}

The objective of this study was to evaluate the effect of prepartum intravaginal administration of an anti-Escherichia coli bacteriophage cocktail on uterine health and reproductive performance of lactating dairy cows. The study was conducted on a commercial dairy farm located near Ithaca, New York, from March to September 2012, and 107 cows were enrolled. The cows were divided randomly into 2 groups (treatment and control); treatment group cows were submitted to 3 intravaginal administrations of $20 \mathrm{~mL}$ of a bacteriophage cocktail including 10 different phages in a lysate with titration of approximately $10^{9}$ plaque-forming units, on d 230, 260, and 275 of gestation. Control cows were not treated with a placebo, and physical examination and sample collection was conducted equally for both groups. Vaginal swabs were collected at d 230, 260, and $275 \mathrm{~d}$ of gestation, cervical swabs were collected at 3 $\pm 1 \mathrm{~d}$ in milk, and blood was collected at $275 \mathrm{~d}$ of gestation for nonesterified fatty acids and interleukin (IL)-6 serum level measurements and at 10 DIM for $\beta$-hydroxybutyrate and IL-6 serum level measurements. The bacteriophage cocktail significantly increased the incidence of retained placenta and metritis. Swab samples were cultured for $E$. coli and no difference was found between treatment and control groups. The lysate contained $6 \times 10^{9}$ IU of lipopolysaccharide $/ \mathrm{mL}$ and could have caused prepartum overstimulation of toll-like receptor-4 (TLR4)-chemokine pathway, leading to a weaker immune response. However, IL-6 was not affected by treatment, although sample size was insufficient to prove a treatment effect on the suppression of the chemokine cascade and innate immune system. Bacteriophage treatment had an excellent bactericidal effect in previous in vitro trials; however, special attention must be given to production of the cocktail to obtain a purified solution free of $E$. coli bacterial products and fragments, particularly lipopolysaccharide.

Received March 7, 2013.

Accepted August 26, 2013.

${ }^{1}$ Corresponding author: rcb28@cornell.edu
Key words: uterine health, bacteriophage, metritis, retained placenta

\section{INTRODUCTION}

Poor reproductive performance is an important production-limiting factor (Gröhn and Rajala-Schultz, 2000). Postpartum uterine diseases, especially metritis, are important for animal welfare reasons, contributing to cow discomfort and elimination from the herd, and for economic reasons, profoundly affecting reproductive performance and reducing the profit potential of dairy farms (Bicalho et al., 2010a). Rajala and Gröhn (1998) reported that second-lactation cows affected with dystocia, retained placenta, or metritis produced 2.2, 1.4, and $1.3 \mathrm{~kg} / \mathrm{d}$ less milk, respectively, compared with healthy herdmates. Therefore, uterine diseases cause substantial economic losses, which are incurred as a consequence of reduced milk yield and costs of culling and treatment. The total cost per case of metritis is estimated to range between $\$ 329$ and $\$ 386$ (Overton and Fetrow, 2008).

The uterine lumen is usually contaminated by bacteria after parturition (Földi et al., 2006). The composition of the bacterial flora in the postpartum uterus of dairy cows differs between healthy cows and those with metritis (Santos et al., 2011). Escherichia coli, Arcanobacterium pyogenes (now named Trueperella pyogenes), and Fusobacterium necrophorum are considered important etiological agents of uterine diseases (Miller et al., 2007; Bicalho et al., 2010a; Santos et al., 2011). The presence of $E$. coli in the uterus is associated with uterine inflammation and impaired reproductive performance (Studer and Morrow, 1978; Bonnett and Martin, 1995; Bondurant, 1999). Zerbe et al. (2001) observed that E. coli products cause a dominant functional depression of neutrophils and suggested that the earlier appearance of $E$. coli in the uterus may support the coinfection of this organ by other etiologic agents at later times. Bicalho et al. (2010a) investigated virulence factors, including the type 1 fimbrial adhesin fimH, and reported that cows with at least one fimH-carrying $E$. coli strain isolated from the uterus had a 4.6-fold increased odds of metritis when compared with $E$. coli negative cows. 
Later, Bicalho et al. (2012) reported that the presence of fimH-carrying $E$. coli at 1 to 3 DIM in the uterus was strongly associated with metritis, and cows that had the fimH-carrying bacteria were 16.2 times more likely to develop $F$. necrophorum intrauterine contamination at 8 to 10 DIM.

Ideally, treatments for uterine diseases should control pathogens in the uterus and result in no or only shortduration milk and meat withdrawal periods. Systemic or intrauterine antibiotic therapy is commonly used as a treatment for metritis, and antibiotic therapy is usually followed by milk and meat withdrawal periods (Azawi, 2008). However, extensive use of antimicrobials in food animal production has contributed to the emergence of antimicrobial resistance among pathogens, which complicates the treatment of infectious diseases (Tollefson et al., 1999).

Bacteriophages are viruses that infect bacteria and are obligate intracellular parasites lacking their own metabolism. Phages are host specific, able to infect only specific species or even strains of bacteria (Barrow and Soothill, 1997). Optimistic results regarding their use against certain bacterial infections have been revealed by recent randomized clinical trials in mice and cattle. Mice were successfully rescued with a single injection of a phage solution containing $3 \times 10^{8}$ plaque-forming units (pfu) of a certain bacteriophage after inoculation with lethal doses of vancomycin-resistant Enterococcus faecium (Biswas et al., 2002). Additionally, Smith and Huggins (1983) reported that bacteriophage therapy was successful when newborn, colostrum-deprived calves were inoculated with $E$. coli and treated with intramuscular injections of a bacteriophage solution.

Our research group isolated environmental bacteriophages using $E$. coli derived from the uterus of postpartum dairy cows (Bicalho et al., 2010b) and evaluated the in vitro antimicrobial activity of a bacteriophage cocktail against intrauterine E. coli (Santos et al., 2010). This bacteriophage cocktail had excellent in vitro bactericidal ability against several genetically distinct strains of $E$. coli previously isolated from intrauterine secretions of metritic cows. In a recent study, using 597 cows, we evaluated the effectiveness of an anti-E. coli bacteriophage cocktail by intrauterine administration at $2 \pm 1$ DIM. The cocktail included 4 different phages, with a dose of approximately $10^{7} \mathrm{pfu}$, but no effects on uterine health and reproductive performance were found (Machado et al., 2012). As mentioned before, the presence of $E$. coli in the uterus at 1 to 3 DIM is highly associated with uterine disease. Therefore, it is possible that in our previous work (Machado et al., 2012), E. coli had already had a detrimental effect on the uterus at the moment of treatment. Sharma et al. (2011) observed that prophylactic peripartal intravagi- nal administration of a probiotic treatment lowered the incidence of metritis and endometritis in dairy cows. Specific strains of E. coli that are more likely to cause uterine diseases may inhabit the lower genital tract of some cows before parturition, predisposing them to metritis, and that bacteriophage treatment might have been more successful if applied prepartum. Additionally, the dosage used for the preparation of the bacteriophage cocktail in Machado et al. (2012) could have been insufficient to treat the bacterial load of the lochial secretion. Therefore, the objective of this study was to evaluate the effect of prepartum intravaginal administration of an anti- $E$. coli bacteriophage cocktail on uterine disease.

\section{MATERIALS AND METHODS}

\section{Farm and Management}

The study was conducted on a commercial dairy farm located near Ithaca, New York, from March to September 2012. This farm was selected because of its long working relationship with the Ambulatory and Production Medicine Clinic at Cornell University. The farm milked 2,800 Holstein cows 3 times daily in a double 52-stall parallel milking parlor. The cows were housed in freestall barns with concrete stalls covered with mattresses and bedded with manure solids. All cows were offered a TMR consisting of approximately $55 \%$ forage (corn silage, haylage, and wheat straw) and $45 \%$ concentrate (corn meal, soybean meal, canola, cottonseed, and citrus pulp) on a DM basis. The diet was formulated to meet or exceed the NRC nutrients requirements (NRC, 2001) for lactating Holstein cows weighing $650 \mathrm{~kg}$ and producing $45 \mathrm{~kg}$ of $3.5 \%$ FCM. The prefreshening diet had 19.25, 108.59, 0.38, and $63.77 \mathrm{mg} / \mathrm{kg}$ of $\mathrm{Cu}, \mathrm{Mn}, \mathrm{Se}$, and $\mathrm{Zn}$ in its composition, respectively; NRC nutrient requirements in prefreshening diet are $13.0,18.0,0.30$, and $22.0 \mathrm{mg} / \mathrm{kg}$, respectively (NRC, 2001). Furthermore, the lactation diet had $20.02,72.85,0.47$, and $80.81 \mathrm{mg} / \mathrm{kg}$ of $\mathrm{Cu}, \mathrm{Mn}$, Se, and $\mathrm{Zn}$ in its composition, respectively; NRC nutrient requirements in lactation diet are 11.0, 13.0, 0.30, and $52.0 \mathrm{mg} / \mathrm{kg}$, respectively (NRC, 2001).

The reproductive management used a combination of Presynch (Moreira et al., 2001), Ovsynch (Pursley et al., 1995), Resynch (Fricke et al., 2003), and detection of estrus, with 25 to $30 \%$ of cows bred via timed AI and the remainder bred after detection of estrus solely by activity monitors (Alpro; DeLaval, Kansas City, MO).

\section{Treatment Groups and Case Definition}

Statistical power and sample size calculations were performed before initiation of the study. Considering a 
sample size of 140 cows per group, a statistical power of 0.8 , a $P$-value of 0.05 , and an overall incidence of metritis of $20 \%$, a reduction in the metritis incidence of $50 \%$ or more between treatment groups would have been detected as statistically significant. Therefore, a total of 280 cows starting their first and second lactations were enrolled in the study (Table 1). A total randomized field trial study design was used; cows were randomly allocated into 1 of 2 groups (treatment or control) using the random number function of Excel (Microsoft Corp., Redmond, WA). The treatment group received an intravaginal administration of $20 \mathrm{~mL}$ of a bacteriophage cocktail including 10 different phages in a lysate with titration of approximately $10^{9} \mathrm{pfu}$, on d 230, 260, and 275 of gestation. The bacteriophages used in the cocktail were isolated and tested in vitro in previous studies (Bicalho et al., 2010b, Santos et al., 2010); multiplicity of infection as low as $10^{-4}$ affected the growth of $E$. coli when tested in vitro. Because the quantity of $E$. coli present in the lower genital tract was unknown, the bacteriophage treatment dose was selected based on treatment production limitations. No treatment was administered to control animals. Unfortunately, after 40 enrolled animals had calved, it became obvious that prepartum intravaginal administration of the bacteriophage cocktail was dramatically inducing retained placenta and metritis and therefore we decided to stop the enrollment of new cows into the study. Consequently, only 107 cows were enrolled in the study, 48 in the control group and 59 in the treatment group.

Vaginal swabs were collected at d 230, 260, and 275 of gestation. A sterile swab protected by a lubricated gloved hand was introduced to the cranial vagina at 3 \pm 1 DIM. After restraining the cows, the perineum area was cleaned and disinfected with $70 \%$ ethanol solution. The swab was manipulated on the cervix and exposed to uterine secretion. The swabs were kept inside a sterile vial at $4^{\circ} \mathrm{C}$ until being processed in the laboratory. They were cultured aerobically on Chromagar (Difco, Becton, Dickinson and Co., Franklin Lakes, NJ) at $37^{\circ} \mathrm{C}$, and E. coli colonies were distinguished by a blue color. At $275 \mathrm{~d}$ of gestation and 10 DIM, blood was collected (puncture of coccygeal vessels) into evacuated tubes without anticoagulant (Vacutainer, Becton, Dickinson and Co., Franklin Lakes, NJ). Metritis was diagnosed at $3 \pm 1$ and $10 \pm 3$ DIM by the research team, as described by Sheldon et al. (2002), being the presence of fetid, watery, red-brown uterine discharge (Sheldon et al., 2006; Martinez et al., 2012). Puerperal metritis was diagnosed daily by farm employees and this information was also analyzed.

Retained placenta was defined as a condition where cows failed to release their fetal membranes within $24 \mathrm{~h}$ of calving (Kelton et al., 1998), and it was diagnosed by the research team. Data regarding reproductive performance were extracted from the farm's DairyComp 305 database (Valley Agricultural Software, Tulare, CA).

Body condition scores were recorded at the time of each sampling using a 5-point scale with a quarter-point increments as described by Edmonson et al. (1989).

\section{Laboratory Analyses}

Blood samples were transported to the laboratory within $4 \mathrm{~h}$, where serum was separated by centrifugation at 2,000 $\times g$ for $15 \mathrm{~min}$, and frozen at $-80^{\circ} \mathrm{C}$ and later analyzed for IL- 6 concentration by ELISA (USCNK Life Sciences Inc., Houston, TX). Serum concentrations of NEFA and BHBA were measured using an enzymatic method. The NEFA-HR (2) kit (Wako Chemicals USA Inc., Richmond, VA) was used for NEFA at 275 d of gestation and the Auto kit 3-HB was used for BHBA at 3 DIM (Wako Chemicals USA Inc.); both were analyzed in the Synergy HT MultiMode Microplate Reader (Bio Tek Instruments Inc., Winooski, VT).

\section{Bacteriophage Cocktail}

The bacteriophage lysate was produced with the large-scale growth of 10 different bacteriophage viruses (Sambrook and Russell, 2001). Ten intrauterine E. coli strains known to be susceptible to each virus strain (Santos et al., 2010) were incubated on Luria-

Table 1. Descriptive data of phage and control groups

\begin{tabular}{lcc}
\hline Variable & Phage & Control \\
\hline Parity 1 (no.) & 70 & 70 \\
Parity 2 (no.) & 70 & 70 \\
Days in pregnancy at enrollment (mean \pm SD) & $225 \pm 5.43$ & $225 \pm 4.54$ \\
BCS (mean \pm SD) & $3.72 \pm 0.20$ & $3.83 \pm 0.23$ \\
50 d prepartum & $3.72 \pm 0.15$ & $3.83 \pm 0.17$ \\
30 d prepartum & $3.74 \pm 0.10$ & $3.84 \pm 0.11$ \\
10 d prepartum & $3.49 \pm 0.10$ & $3.64 \pm 0.11$ \\
3 d postpartum & $3.45 \pm 0.10$ & $3.5 \pm 0.11$ \\
\hline d d postpartum & & \\
\hline
\end{tabular}


Bertani broth (Difco) for $8 \mathrm{~h}$ at $37^{\circ} \mathrm{C}$. Bacteriophage previously tested were inoculated on each culture and incubated for $8 \mathrm{~h}$ at $37^{\circ} \mathrm{C}$. After centrifugation for 15 $\min \left(11,000 \times g, 4^{\circ} \mathrm{C}\right)$, the supernatant was removed, sterile filtered $(0.22 \mu \mathrm{m})$, and stored at 2 to $8^{\circ} \mathrm{C}$ until use. The enumeration of bacteriophages in each lysate was done using a small drop plaque assay (Mazzocco et al., 2009). Bacteriophage treatments were prepared by adding equal amounts of each lysate.

The lysate was controlled for bacterial contamination by culturing on LB media and incubating it for $8 \mathrm{~h}$ at $37^{\circ} \mathrm{C}$, before treatment and after its interruption. The assessment of the endotoxin levels on the bacteriophage lysate was performed after treatment interruption using the Limulus amoebocyte lysate Endpoint Assay (Hycult Biotech, Uden, the Netherlands) following the manufacturer's instructions.

\section{Statistical Analysis}

To evaluate the effects of treatment on postpartum diseases, on vaginal swab cultures, and on the outcome of the intrauterine secretion cultures, multivariable logistic regression models were fitted to the data using the LOGISTIC procedure of SAS (SAS Institute Inc., Cary, NC). The incidence of metritis at 3 and $10 \mathrm{~d}$ postpartum, puerperal metritis, retained placenta, mastitis, and presence of E. coli at 30 and $10 \mathrm{~d}$ prepartum and at 3 d postpartum were separately analyzed. Parity number and treatment group were offered in all models as categorical variables. To control the confounding effect of parity and BCS before enrollment, these variables were forced into all logistic regression models.

One-way ANOVA in JMP Pro (SAS Institute Inc.) was used to evaluate the effects of parity, treatment, and postpartum diseases on NEFA serum levels at 10 d prepartum, BHBA serum levels at 10 DIM, and IL-6 serum levels at $10 \mathrm{~d}$ prepartum and 10 DIM.

Effects of treatment on calving-to-conception interval as well as on cow survivability were estimated with the use of Kaplan-Meier hazard analysis in Medcalc (version 12.3.0, Medcalc Software, Ostend, Belgium). For all statistical models, main effects and interaction terms were considered significant at $P<0.05$.

\section{RESULTS}

\section{Effect of Bacteriophage Cocktail on Postpartum Metritis, Retained Placenta, and Mastitis}

The prophylactic treatment tested did not have the expected effect on the outcome of culture of vaginal and cervical secretions: the incidence of positive $E$. coli cultures at $30 \mathrm{~d}$ prepartum $(P=0.81), 10 \mathrm{~d}$ prepartum $(P$
$=0.87)$, and $10 \mathrm{~d}$ postpartum $(P=0.90)$ did not differ between treatment and control group (Figure 1). Treatment was unsuccessful in the prevention of metritis; treated cows had $7.48(P=0.07)$ and $3.16(P=0.009)$ higher odds of being diagnosed as metritic at 3 and $10 \mathrm{~d}$ postpartum, respectively, compared with control cows; treated cows had $2.79(P=0.03)$ increased odds of being diagnosed with puerperal metritis compared with control cows. Moreover, we observed a tendency for an increased incidence of retained placenta $(P=$ 0.09 ), and treated cows were 6.67 times more likely to develop retained placenta (Table 2 ).

\section{BCS, NEFA, BHBA, and IL-6}

The effect of treatment on BCS evaluated at different time points: $30(P=0.37)$ and $10(P=0.23) \mathrm{d}$ prepartum, and $3(P=0.08)$ and $10(P=0.60)$ d postpartum, was not statistically significant.

The effect of parity, treatment, and postpartum diseases on NEFA at $10 \mathrm{~d}$ prepartum, BHBA at 10 d postpartum, and IL-6 at $10 \mathrm{~d}$ prepartum and $10 \mathrm{~d}$ postpartum are described in Table 3. Briefly, control animals had numerically higher serum BHBA levels at 10 postpartum $(P=0.09)$ and numerically lower levels of serum IL-6 at $10 \mathrm{~d}$ postpartum for animals diagnosed with puerperal metritis $(P=0.09)$, but we observed no significant differences for either variable.

\section{Effect of Bacteriophage Therapy on Reproductive Performance and Survivability}

The bacteriophage therapy numerically increased calving-to-conception interval $(P=0.09)$ : the median calving-to-conception interval was 130 and $99 \mathrm{~d}$ for

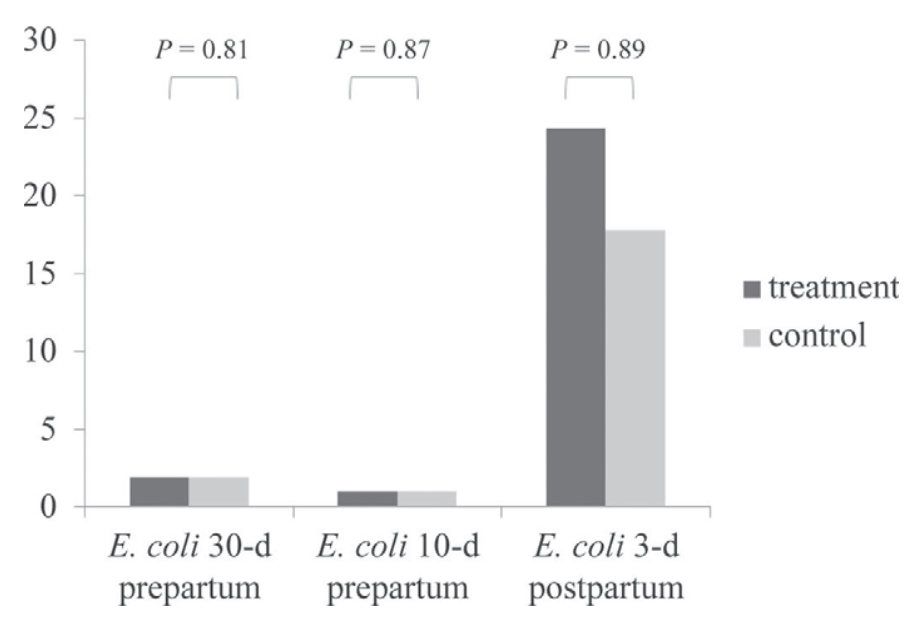

Figure 1. Effect of treatment on the outcome of vaginal swab culture at 30 and $10 \mathrm{~d}$ prepartum and cervical swab at $3 \mathrm{~d}$ postpartum. 
Table 2. Effect of treatment on postpartum diseases

\begin{tabular}{|c|c|c|c|c|}
\hline Variable & Group & $\begin{array}{c}\text { Adjusted } \\
\text { incidence }(95 \% \text { CI })\end{array}$ & $\begin{array}{l}\text { Odds ratio } \\
(95 \% \mathrm{CI})\end{array}$ & $P$-value \\
\hline Metritis at $3 \mathrm{~d}$ postpartum & Control & $\begin{array}{l}0.02(0.003-0.14) \\
0.14(0.07-0.25)\end{array}$ & $\begin{array}{c}\text { Reference } \\
748(0.89-6185)\end{array}$ & 0.07 \\
\hline Metritis at $10 \mathrm{~d}$ postpartum & $\begin{array}{l}\text { Control } \\
\text { Treatment }\end{array}$ & $\begin{array}{l}0.25(0.15-0.40) \\
0.52(0.38-0.65)\end{array}$ & $\begin{array}{c}\text { Reference } \\
3.16(1.36-7.33)\end{array}$ & 0.009 \\
\hline Puerperal metritis & $\begin{array}{l}\text { Control } \\
\text { Treatment }\end{array}$ & $\begin{array}{l}0.17(0.09-0.31) \\
0.37(0.25-0.51)\end{array}$ & $\begin{array}{c}\text { Reference } \\
2.79(1.14-6.85)\end{array}$ & 0.03 \\
\hline Retained placenta & $\begin{array}{l}\text { Control } \\
\text { Treatment }\end{array}$ & $\begin{array}{l}0.01(0.002-0.11) \\
0.08(0.03-0.22)\end{array}$ & $\begin{array}{c}\text { Reference } \\
6.67(0.78-57.07)\end{array}$ & 0.09 \\
\hline Mastitis & $\begin{array}{l}\text { Control } \\
\text { Treatment }\end{array}$ & $\begin{array}{l}0.19(0.09-0.33) \\
0.24(0.14-0.37)\end{array}$ & $\begin{array}{c}\text { Reference } \\
1.36(0.51-3.60)\end{array}$ & 0.54 \\
\hline
\end{tabular}

treatment and control cows, respectively (Figure 2), without significance. Treatment had no effect on survivability $(P=0.78$; Figure 3$)$.

\section{LPS Concentration on Bacteriophage Cocktail}

The bacterial culture of the bacteriophage cocktail was negative, and the level of endotoxin was $6 \times 10^{9}$ IU of LPS/mL.

\section{DISCUSSION}

Encouraged by results of previous studies, we performed this clinical trial with the aim of establishing alternatives for prophylaxis of postpartum uterine diseases. Given the growing interest in reducing the use of antibiotics in farm animals, any positive results from this study could be considered important. Bacteriophages were expected to be beneficial for metritis prevention, decreasing the bacterial load of E. coli and therefore decreasing the severity of the disease (Sheldon et al., 2006). Bacteriophages have been used successfully in animal trials against a broad range of pathogenic E. coli (Brüssow, 2005). Previous studies isolated environmental bacteriophages using $E$. coli isolated from postpartum uterus, estimated their lytic activity (Bicalho et al., 2010b), and evaluated the in vitro antimicrobial activity of a bacteriophage cocktail against intrauterine E. coli (Bicalho et al., 2010b; Santos et al., 2010). This cocktail had the capacity to inhibit the in vitro growth of $E$. coli isolates, but had no visible effect on reproduction performance or incidence of metritis or endometritis when evaluated in an early postpartum bacteriophage treatment on cows (Machado et al.,

Table 3. Effect of parity, treatment, and postpartum diseases on NEFA at $10 \mathrm{~d}$ prepartum, BHBA at 10 DIM, and IL-6 at $10 \mathrm{~d}$ prepartum and 10 DIM

\begin{tabular}{|c|c|c|c|c|}
\hline \multirow[b]{2}{*}{ Variable } & \multirow[b]{2}{*}{ NEFA (95\% CI) } & \multirow[b]{2}{*}{$\mathrm{BHBA}(95 \% \mathrm{CI})$} & \multicolumn{2}{|c|}{ IL-6 $(95 \% \mathrm{CI})$} \\
\hline & & & At $10 \mathrm{~d}$ prepartum & At 10 DIM \\
\hline Parity 1 & $0.27(0.24-0.29)$ & $0.37(0.34-0.39)$ & $264.0(164.7-363.4)$ & $181.5(115.9-247.1)$ \\
\hline Parity 2 & $0.24(0.22-0.27)$ & $0.33(0.30-0.37)$ & $282.2(57.3-168.2)$ & $168.11(92.8-243.4)$ \\
\hline$P$-value & 0.20 & 0.15 & 0.81 & 0.79 \\
\hline Phage & $0.26(0.23-0.28)$ & $0.33(0.30-0.36)$ & $274.9(171.3-378.5)$ & $155.5(87.3-223.7)$ \\
\hline Control & $0.26(0.23-0.28)$ & $0.37(0.34-0.40)$ & $268.5(160.2-377.0)$ & $197.8(126.5-269.2)$ \\
\hline$P$-value & 0.94 & 0.09 & 0.93 & 0.40 \\
\hline Metritis 3 prepartum no & $0.26(0.24-0.26)$ & $0.36(0.33-0.38)$ & $283.2(205.6-360.8)$ & $181.9(130.5-233.2)$ \\
\hline Metritis 3 prepartum yes & $0.25(0.19-0.32)$ & $0.32(0.24-0.40)$ & $140.9(0.01-405.0)$ & $104.7(0.01-279.5)$ \\
\hline$P$-value & 0.89 & 0.38 & 0.31 & 0.40 \\
\hline Metritis 10 postpartum no & $0.25(0.23-0.28)$ & $0.35(0.31-0.37)$ & $298.1(200.0-396.1)$ & $193.1(128.4-257.9)$ \\
\hline Metritis 10 postpartum yes & $0.26(0.23-0.29)$ & $0.36(0.33-0.40)$ & $235.7(120.6-350.9)$ & $151.7(75.7-227.8)$ \\
\hline$P$-value & 0.70 & 0.47 & 0.42 & 0.41 \\
\hline Puerperal metritis no & $0.25(0.23-0.27)$ & $0.35(0.33-0.38)$ & $310.3(221.5-399.1)$ & $203.5(145.0-262.0)$ \\
\hline Puerperal metritis yes & $0.27(0.24-0.30)$ & $0.35(0.31-0.39)$ & $185.0(51.6-318.4)$ & $112.9(25.0-200.8)$ \\
\hline$P$-value & 0.37 & 0.80 & 0.12 & 0.09 \\
\hline Retained placenta no & $0.25(0.25-0.27)$ & $0.35(0.30-0.38)$ & $281.7(204.5-358.9)$ & $185.5(134.9-236.2)$ \\
\hline Retained placenta yes & $0.30(0.23-0.36)$ & $0.34(0.26-0.42)$ & $136.9(0.01-422.3)$ & $41.4(0.01-228.6)$ \\
\hline$P$-value & 0.20 & 0.77 & 0.33 & 0.14 \\
\hline Mastitis no & $0.25(0.23-0.27)$ & $0.35(0.33-0.38)$ & $282.4(195.9-368.8)$ & $191.5(134.8-248.3)$ \\
\hline Mastitis yes & $0.27(0.24-0.31)$ & $0.35(0.30-0.40)$ & $240.2(90.6-389.9)$ & $128.3(30.0-226.6)$ \\
\hline$P$-value & 0.32 & 0.94 & 0.63 & 0.27 \\
\hline
\end{tabular}




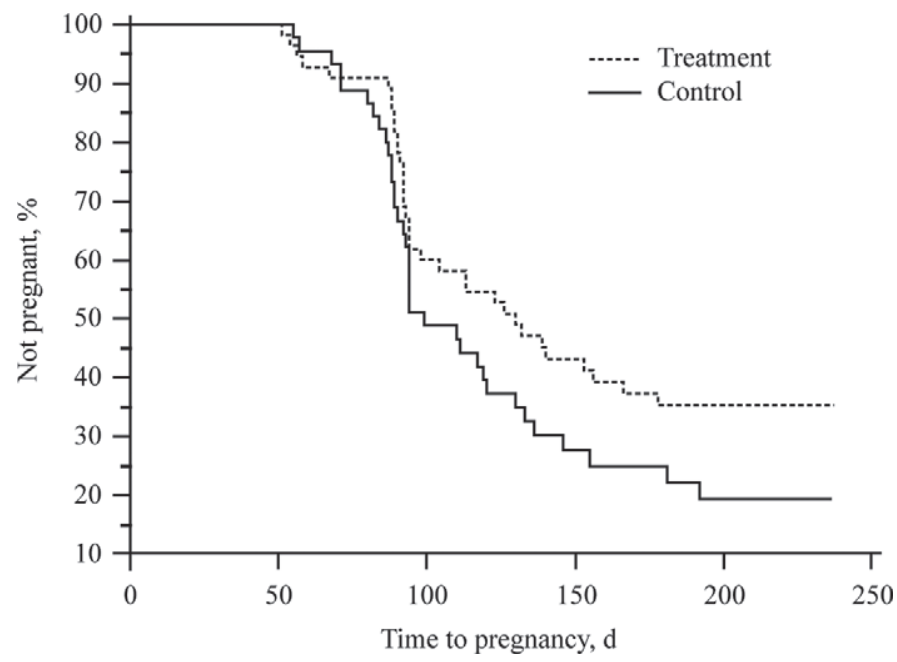

Figure 2. Effect of treatment on calving-to-conception interval. Cows that received prepartum bacteriophage therapy had a median calving-to-conception interval of $130 \mathrm{~d}$ compared with $99 \mathrm{~d}$ for the control cows $(P$-value $=0.09)$.

2012). Assuming that it was a safe treatment and that the absence of any beneficial effects of bacteriophage treatment reported by Machado et al. (2012) could be due to mistimed treatment or to the inadequate dosage used, we performed the study described here treating cows prepartum with a significantly increased dose of bacteriophage. Unfortunately, this led to a significant increase in the incidence of retained placenta and metritis. It is important to note that no bacterial contamination was observed in the bacteriophages lysates and that we observed no difference between treatment and control groups in regard to the number of animals with positive cultures for $E$. coli.

Innate immunity from neutrophils is the primary means of immune response in the uterus, and reduced neutrophil migration and phagocytic and oxidative activity are associated with the risk of retained placenta (Kimura et al., 2002), metritis, and endometritis (Hammon et al., 2006). Elimination of bacterial infections through phagocytosis involves recruitment of neutrophils from the circulation and bone marrow by chemotaxis to sites of infection (Beutler et al., 2003); the presence of invading bacteria is quickly detected by specialized immune cells and cells of the endometrium, which are armed with toll-like receptors (TLR) for the detection of bacterial ligands. Bovine endometrial cells express TLR4, which binds to the LPS of E. coli and other gram-negative bacteria (Herath et al., 2006a,b). In conjunction with CD14 and other accessory molecules, TLR4 initiates a signaling cascade that stimulates the production of nitric oxide, tumor necrosis factor- $\alpha$, IL6, IL8, and other proinflammatory cytokines, which or-

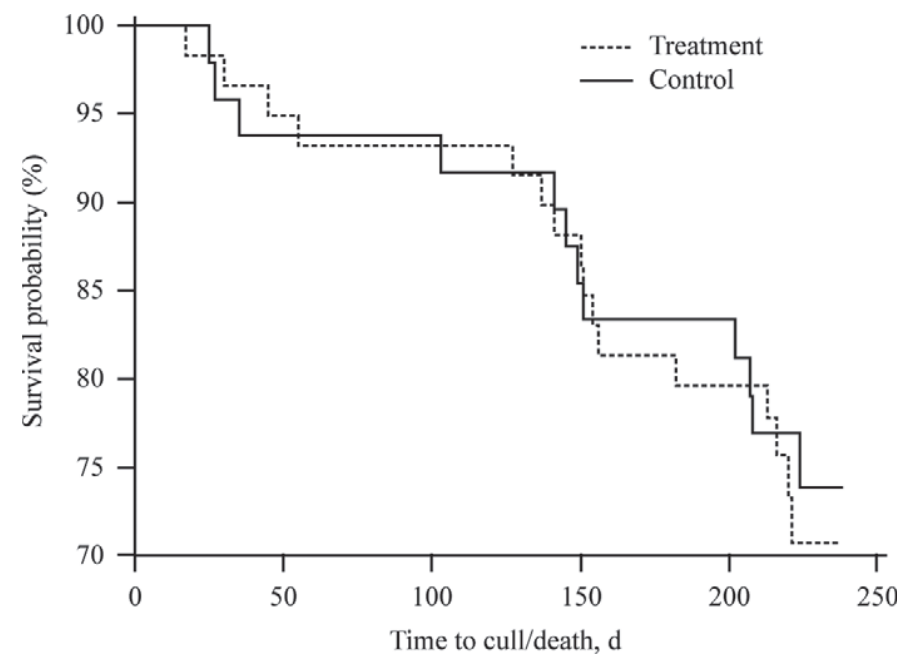

Figure 3. Effect of treatment on survivability. Cows that received prepartum bacteriophage therapy presented the same survival probability when compared with the control cows $(P$-value $=0.78)$.

chestrate an immune response to clear infection, mobilizing and activating immune cells (Beutler et al., 2003; Beutler, 2004; Takeda and Akira, 2004).

Interleukin- 6 is a proinflammatory cytokine produced during the early stages of inflammation. It activates mature neutrophils and promotes neutrophil maturation, differentiation of monocytes into mature macrophages, and differentiation of natural killer cells. It also acts as a growth factor and induces expression of oxytocin receptors on myometrial cells, which increases their responsiveness to oxytocin. Interleukin-6 is present in the bovine uterus in high concentrations before parturition and decreases to baseline values by $8 \mathrm{~d}$ after parturition. High levels of IL6 are associated with bovine endometritis, whereas low levels are associated with retention of the placenta (Ishikawa et al., 2004). In the present study, IL-6 was measured to evaluate the effect of LPS content of the treatment on chemokine response. The bacteriophage lysate contained $6 \times 10^{9} \mathrm{IU}$ of LPS/ $\mathrm{mL}$. However, it was not possible to prove a prepartum overstimulation and exhaustion of the TLR4-cytokine pathway. Although there was a numerical difference in serum IL-6 concentration during the postpartum period, insufficient statistical power prevented us from proving this hypothesis. No difference was found in serum IL-6 concentration among treatment and control groups or among diseased and healthy animals. This antigenic stimulation in the prepartum period caused by the levels of endotoxin in the bacteriophage cocktail might have overcome the bone marrow's capacity to produce enough PMNL to deal with the postpartum demand to clear uterine contamination and to detach the placenta. Intramuscular injection of $E$. coli endo- 
toxin has previously been associated with leucopenia in calves (Yagi and Nakajima, 1983).

Another possible explanation would be that $E$. coli-soluble products other than LPS present in the bacteriophage lysate may have compromised neutrophil function in the genital tract. Zerbe et al. (2002) observed that lochial secretions of healthy cows only moderately affected the function of PMNL, whereas secretions of cows with uterine infection severely depressed the generation of reactive oxygen species; Zerbe et al. (2001) observed that neutrophils incubated with E. coli-soluble products and fragments presented alterations in function and phenotype. In the same study, inhibition experiments with polymyxin B demonstrated that $E$. coli-mediated effects were not solely due to the action of LPS.

Concentrations of NEFA at $10 \mathrm{~d}$ prepartum and BHBA at $10 \mathrm{~d}$ postpartum were measured to provide information regarding the energy balance status of cow; however, no difference was observed between treatment and control groups, indicating that the negative effect on uterine health was mostly caused by treatment.

\section{CONCLUSIONS}

The negative effects produced by $E$. coli fragments and soluble products observed in the present study confirm the importance of this pathogen in the onset of uterine disease, as reported by others (Zerbe et al., 2001; Bicalho et al., 2012; Machado et al., 2012). In previous in vitro trials, bacteriophages were reported to be effective against $E$. coli strains isolated from diseased cows (Santos et al., 2010). However, in agreement with previous work by Machado et al., (2012), we find no evidence that bacteriophage therapy is beneficial when used in vivo.

\section{REFERENCES}

Azawi, O. I. 2008. Postpartum uterine infection in cattle. Anim. Reprod. Sci. 105:187-208.

Barrow, P. A., and J. S. Soothill. 1997. Bacteriophage therapy and prophylaxis: Rediscovery and renewed assessment of potential. Trends Microbiol. 5:268-271.

Beutler, B. 2004. Innate immunity: An overview. Mol. Immunol. 40:845-859.

Beutler, B., K. Hoebe, X. Du, and R. J. Ulevitch. 2003. How we detect microbes and respond to them: The toll-like receptors and their transducers. J. Leukoc. Biol. 74:479-485.

Bicalho, M. L. S., V. S. Machado, G. Oikonomou, R. O. Gilbert, and R. C. Bicalho. 2012. Association between virulence factors of Escherichia coli, Fusobacterium necrophorum, and Arcanobacterium pyogenes and uterine diseases of dairy cows. Vet. Microbiol. 157:125-131.

Bicalho, R. C., V. S. Machado, M. L. Bicalho, R. O. Gilbert, A. G. Teixeira, L. S. Caixeta, and R. V. Pereira. 2010a. Molecular and epidemiological characterization of bovine intrauterine Escherichia coli. J. Dairy Sci. 93:5818-5830.
Bicalho, R. C., T. M. Santos, R. O. Gilbert, L. S. Caixeta, L. M. Teixeira, M. L. Bicalho, and V. S. Machado. 2010b. Susceptibility of Escherichia coli isolated from uteri of postpartum dairy cows to antibiotic and environmental bacteriophages. Part I: Isolation and lytic activity estimation of bacteriophages. J. Dairy Sci. 93:93104.

Biswas, B., S. Adhya, P. Washart, B. Paul, A. N. Trostel, B. Powell, R. Carlton, and C. R. Merril. 2002. Bacteriophage therapy rescues mice bacteremic from a clinical isolate of vancomycin-resistant $E n-$ terococcus faecium. Infect. Immun. 70:204-210.

Bondurant, R. H. 1999. Inflammation in the bovine female reproductive tract. J. Anim. Sci. 77(Suppl. 2):101-110.

Bonnett, B. N., and S. W. Martin. 1995. Path analysis of peripartum and postpartum events, rectal palpation findings, endometrial biopsy results and reproductive performance in Holstein-Friesian dairy cows. Prev. Vet. Med. 21:279-288.

Brüssow, H. 2005. Phage therapy: The Escherichia coli experience. Microbiology 151:2133-2140.

Edmonson, A. J., I. J. Lean, L. D. Weaver, T. Farver, and G. Webster. 1989. A body condition scoring chart for Holstein dairy cows. J. Dairy Sci. 72:68-78

Földi, J., M. Kulcsár, A. Pécsi, B. Huyghe, C. de Sa, J. A. C. M. Lohuis, P. Cox, and G. Huszenicza. 2006. Bacterial complications of postpartum uterine involution in cattle. Anim. Reprod. Sci 96:265-281.

Fricke, P. M., D. Z. Caraviello, K. A. Weigel, and M. L. Welle. 2003 Fertility of dairy cows after resynchronization of ovulation at three intervals following first timed insemination. J. Dairy Sci. 86:3941-3950.

Gröhn, Y. T., and P. J. Rajala-Schultz. 2000. Epidemiology of reproductive performance in dairy cows. Anim. Reprod. Sci. 6061:605-614.

Hammon, D. S., I. M. Evjen, T. R. Dhiman, J. P. Goff, and J. L. Walters. 2006. Neutrophil function and energy status in Holstein cows with uterine health disorders. Vet. Immunol. Immunopathol. 113:21-29.

Herath, S., H. Dobson, C. E. Bryant, and I. M. Sheldon. 2006a. Use of the cow as a large animal model of uterine infection and immunity. J. Reprod. Immunol. 69:13-22.

Herath, S., D. P. Fischer, D. Werling, E. J. Williams, S. T. Lilly, H. Dobson, C. E. Bryant, and I. M. Sheldon. 2006b. Expression and function of toll-like receptor 4 in the endometrial cells of the uterus. Endocrinology 147:562-570.

Ishikawa, Y., K. Nakada, K. Hagiwara, R. Kirisawa, H. Iwai, M. Moriyoshi, and Y. Sawamukai. 2004. Changes in interleukin-6 concentration in peripheral blood of pre- and post-partum dairy cattle and its relationship to postpartum reproductive diseases. J. Vet. Med. Sci. 66:1403-1408.

Kelton, D. F., K. D. Lissemore, and R. E. Martin. 1998. Recommendations for recording and calculating the incidence of selected clinical diseases of dairy cattle. J. Dairy Sci. 81:2502-2509.

Kimura, K., J. P. Goff, M. E. Kehrli, and T. A. Reinhardt. 2002. Decreased neutrophil function as a cause of retained placenta in dairy cattle. J. Dairy Sci. 85:544-550.

Machado, V. S., M. L. Bicalho, R. V. Pereira, L. S. Caixeta, J. H. Bittar, G. Oikonomou, R. O. Gilbert, and R. C. Bicalho. 2012. The effect of intrauterine administration of mannose or bacteriophage on uterine health and fertility of dairy cows with special focus on Escherichia coli and Arcanobacterium pyogenes. J. Dairy Sci. 95:3100-3109

Martinez, N., C. A. Risco, F. S. Lima, R. S. Bisinotto, L. F. Greco, E. S. Ribeiro, F. Maunsell, K. Galvao, and J. E. Santos. 2012. Evaluation of peripartal calcium status, energetic profile, and neutrophil function in dairy cows at low or high risk of developing uterine disease. J. Dairy Sci. 95:7158-7172.

Mazzocco, A., T. E. Waddell, E. Lingohr, and R. P. Johnson. 2009. Enumeration of bacteriophages using the small drop plaque assay system. Methods Mol. Biol. 501:81-85.

Miller, A. N., E. J. Williams, K. Sibley, S. Herath, E. A. Lane, J. Fishwick, D. M. Nash, A. N. Rycroft, H. Dobson, C. E. Bryant, and I. M. Sheldon. 2007. The effects of Arcanobacterium pyogenes on 
endometrial function in vitro, and on uterine and ovarian function in vivo. Theriogenology 68:972-980.

Moreira, F., C. Orlandi, C. A. Risco, R. Mattos, F. Lopes, and W. W. Thatcher. 2001. Effects of resynchronization and bovine somatotropin on pregnancy rates to a timed artificial insemination protocol in lactating dairy cows. J. Dairy Sci. 84:1646-1659.

NRC. 2001. Nutrient Requirements of Dairy Cattle. 7th rev. ed. Natl. Acad. Press, Washington, DC.

Overton, M., and J. Fetrow. 2008. Economics of postpartum uterine health. Dairy Cattle Reproduction Council Convention, Omaha, NE.

Pursley, J. R., M. O. Mee, and M. C. Wiltbank. 1995. Synchronization of ovulation in dairy cows using PGF2alpha and GnRH. Theriogenology 44:915-923.

Rajala, P. J., and Y. T. Gröhn. 1998. Effects of dystocia, retained placenta, and metritis on milk yield in dairy cows. J. Dairy Sci. 81:3172-3181.

Sambrook, J., and D. W. Russell. 2001. Molecular Cloning: A Laboratory Manual. 3rd ed. Cold Spring Harbor Laboratory Press, Cold Spring Harbor, NY.

Santos, T. M., R. O. Gilbert, and R. C. Bicalho. 2011. Metagenomic analysis of the uterine bacterial microbiota in healthy and metritic postpartum dairy cows. J. Dairy Sci. 94:291-302.

Santos, T. M., R. O. Gilbert, L. S. Caixeta, V. S. Machado, L. M. Teixeira, and R. C. Bicalho. 2010. Susceptibility of Escherichia coli isolated from uteri of postpartum dairy cows to antibiotic and environmental bacteriophages. Part II: In vitro antimicrobial activity evaluation of a bacteriophage cocktail and several antibiotics. J. Dairy Sci. 93:105-114.

Sharma, S., Q. Zebeli, S. Iqbal, S. M. Dunn, J. F. Odhiambo, M. Gänzele, and B. N. Ametaj. 2011. Peripartal intravaginal application of probiotic bacteria lowered the incidence of uterine infections and improved fertility in dairy cows. J. Dairy Sci. 89(E-Suppl. 1):18. (Abstr.)

Sheldon, I. M., G. S. Lewis, S. LeBlanc, and R. O. Gilbert. 2006. Defining postpartum uterine disease in cattle. Theriogenology 65:1516-1530.

Sheldon, I. M., D. E. Noakes, A. N. Rycroft, and H. Dobson. 2002. Effect of postpartum manual examination of the vagina on uterine bacterial contamination in cows. Vet. Rec. 151:531-534.

Smith, H. W., and M. B. Huggins. 1983. Effectiveness of phages in treating experimental Escherichia coli diarrhoea in calves, piglets and lambs. J. Gen. Microbiol. 129:2659-2675.

Studer, E., and D. A. Morrow. 1978. Postpartum evaluation of bovine reproductive potential: Comparison of findings. J. Am. Vet. Med. Assoc. 172:489-494.

Takeda, K., and S. Akira. 2004. TLR signaling pathways. Semin. Immunol. 16:3-9.

Tollefson, L., P. J. Fedorka-Cray, and F. J. Angulo. 1999. Public health aspects of antibiotic resistance monitoring in the USA. Acta Vet. Scand. Suppl. 92:67-75.

Yagi, Y., and Y. Nakajima. 1983. Changes in leukocyte count, blood glucose and coagulation system in calves injected with Escherichia coli endotoxin. Natl. Inst. Anim. Health Q. (Tokyo) 23:158-160.

Zerbe, H., C. Ossadnik, W. Leibold, and H. J. Schuberth. 2001. Influence of Escherichia coli and Arcanobacterium pyogenes isolated from bovine puerperal uteri on phenotypic and functional properties of neutrophils. Vet. Microbiol. 79:351-365.

Zerbe, H., C. Ossadnik, W. Leibold, and H. J. Schuberth. 2002. Lochial secretions of Escherichia coli- or Arcanobacterium pyogenesinfected bovine uteri modulate the phenotype and the functional capacity of neutrophilic granulocytes. Theriogenology 57:11611177. 